\section{Analysis on misdiagnosis of a case of novel variant of NLRP12}

We had read with great interest the paper about undefined systemic autoinflammatory diseases (SAIDs) by Ter Haar et al. ${ }^{1}$ We noticed heterogeneity of presentation in SAIDs, is difficult to diagnose, and there are no standard medications for the treatment. Here, we report a case with novel variant in NLRP12 was misdiagnosed as refractory systemic-onset juvenile idiopathic arthritis (sJIA) for 2 years.

A 9-year-old girl presented with arthralgia for 2 months and skin rash on her trunk and fever for 10 days, despite antibiotic therapy. The affected joints were both knees and wrists. She was admitted to our department for an initial evaluation in June 2016. Laboratory investigations include the blood count (white blood count (WBC) $9.03 \times 10 \wedge 9 / \mathrm{L}$, platelet count (PLT) $508 \times 10 \wedge 9 / \mathrm{L}$ ), inflammatory parameters (high C-reactive protein (CRP) $117.7 \mathrm{mg} / \mathrm{L}$, erythrocyte sedimentation rate (ESR) $108 \mathrm{~mm} /$ hour, serum ferritin $628.6 \mathrm{ug} / \mathrm{L}$, interleukin-6 (IL-6) $325.3 \mathrm{pg} / \mathrm{L}$ ). Serum creatinine, transaminase and procalcitonin levels were within normal limits, whereas results for rheumatoid factor, antinuclear antibody, anti-cyclic-citrullinated peptide antibodies, and human leukocyte antigen (HLA) B27 tests were negative. The bone marrow smearand chest CT had no abnormal changes. MRI of the right hand demonstrated swelling in softtissues, and abnormal signs were seen in the subcutaneous and interstitial. Ultrasound of knee joint showed synovial thickening and patellar bursal effusion. Based on the clinical, laboratory and radiologic findings, the diagnosis of sJIA was made. After remission, the patient received prednisolone $(1.5 \mathrm{mg} / \mathrm{kg}$ by mouth daily), methotrexate $\left(10 \mathrm{mg} / \mathrm{m}^{2}\right.$ po weekly), folate $\left(5 \mathrm{mg} / \mathrm{m}^{2}\right.$ po three times/week).

After 3 months, the patient presented with similar symptoms. Therefore, tocilizumab injection $(12 \mathrm{mg} / \mathrm{kg}$ every 2 weeks for the first 3 months and per month subsequently) was given. She had no fever, and inflammatory parameters also returned to normal ranges. However, in the second half of 2017, when the prednisolone decreased to $0.5 \mathrm{mg} / \mathrm{kg} /$ day, elevation of inflammatory parameters and fever recurred, and repeated MRI of the right hand revealed minimal improvement of arthritis. The exome sequencing of immune genome revealed a novel mutation in the exon 4 of the NLRP12 gene (c.2129t>c:p.L710P). Sanger sequencing confirmed the mutation was inherited from her father, who denied any symptoms. It has not been reported in literature yet. Then, tocilizumab was discontinued, and changed to prednisolone $(1.5 \mathrm{mg} / \mathrm{kg}$ by mouth daily) and methotrexate $(10 \mathrm{mg} / \mathrm{m} 2$ by mouth weekly) since 2018. At follow-up, her inflammatory parameters are still abnormal, but without any symptoms.

Our patient presented with fever, arthralgia in knees, wrists and skin rash is in accordance with clinical diagnosis criterion of sJIA, which is different from previous reports. ${ }^{2-4}$ But after a period of time of standard treatment were ineffective. Afterwards, in the first year, the addition of tocilizumab controlled the progression to some extent. As soon as the dosage of steroid was decreased, she presented again fever and arthralgia. Genetic studies confirmed that she did not suffer from sJIA, but carried a novel mutation of NLRP12. Thus, we speculate that the recurrent symptom is due to the reduction of steroids, so we discontinued tocilizumab. Finally, it confirmed that she has a good response with steroids. More research is needed to see if patients with a regular pattern of febrile episodes will have a good response to steroids. ${ }^{1}$ But our patient is still in low disease activity. Long-term prognosis still needs further follow-up. The non-specific clinical manifestations of the NLRP12 mutation may cause misdiagnosis. As more and more cases were found, it may increase the knowledge of NLRP12 and improve the diagnostic rate.

\section{Xiran Yang $\odot$, Bo Zhao, Yabin Liao}

Department of Nephrology and Rheumatology, Kunming Children's Hospital, Kunming, China

Correspondence to Dr Xiran Yang, Kunming Children's Hospital, Kunming 650000, China; 20491603@qq.com

Contributors The conception and design of the correspondence, acquisition of data and analysis and interpretation of data: $X Y$. Drafting the article: $X Y$ and BZ. Involved in care of the patient: BZ and YL. Revising it critically for important intellectual content: BZ and YL; Final approval of the version to be submitted: all authors; agreement to be accountable for all aspects of the work in ensuring that questions related to the accuracy or integrity of any part of the work are appropriately investigated and resolved: all authors.

Funding The authors have not declared a specific grant for this research from any funding agency in the public, commercial or not-for-profit sectors.

Competing interests None declared.

Patient and public involvement Patients and/or the public were not involved in the design, or conduct, or reporting, or dissemination plans of this research.

Patient consent for publication Not required.

Provenance and peer review Not commissioned; internally peer reviewed.

(C) Author(s) (or their employer(s)) 2020. No commercial re-use. See rights and permissions. Published by BMJ.

\section{Check for updates}

To cite Yang X, Zhao B, Liao Y. Ann Rheum Dis Epub ahead of print: [please include Day Month Year]. doi:10.1136/annrheumdis-2020-218422

Received 24 June 2020

Accepted 26 June 2020

Ann Rheum Dis 2020;0:1. doi:10.1136/annrheumdis-2020-218422

ORCID iD

Xiran Yang http://orcid.org/0000-0002-2885-1398

\section{REFERENCES}

1 Ter Haar NM, Eijkelboom C, Cantarini L, et al. Clinical characteristics and genetic analyses of 187 patients with undefined autoinflammatory diseases. Ann Rheum Dis 2019;78:1405-11.

2 Gupta L, Ahmed S, Singh B, et al. Novel NLRP12 variant presenting with familial cold autoimmunity syndrome phenotype. Ann Rheum Dis 2019:annrheumdis-2019-216158

3 Ghosh K. NLRP12 gene mutation in India: case finding and diagnosis made easy in the days of whole exome sequencing. Ann Rheum Dis 2019:annrheumdis-2019-216270.

4 Wang J, Zhang Q, Xu L, et al. A case of episodic and refractory arthritis due to a novel variant of NLRP12. Ann Rheum Dis 2020:annrheumdis-2020-217023. 